Please do not remove this page

RMIT

UNIVERSITY

\title{
Footloose transients: International students in Australia and their aspirations for transnational mobility after graduation
}

Gomes, Catherine

https://researchrepository.rmit.edu.au/esploro/outputs/9921862244801341/filesAndLinks?institution=61RMIT_INST\&index=null

Gomes, C. (2015). Footloose transients: International students in Australia and their aspirations for transnational mobility after graduation. Crossings: Journal of Migration \& Culture, 6(1), 41-57.

https://doi.org/10.1386/cjmc.6.1.41_1

Document Version: Accepted Manuscript

Published Version: https://doi.org/10.1386/cjmc.6.1.41_1

Repository homepage: https://researchrepository.rmit.edu.au

(C) Intellect Ltd.

Downloaded On 2023/04/26 16:44:53 +1000 
Thank you for downloading this document from the RMIT Research Repository.

The RMIT Research Repository is an open access database showcasing the research outputs of RMIT University researchers.

RMIT Research Repository: http://researchbank.rmit.edu.au/

\section{Citation:}

Gomes, C 2015, 'Footloose transients: International students in Australia and their aspirations for transnational mobility after graduation', Crossings: Journal of Migration \& Culture, vol. 6, no. 1, pp. 41-57.

See this record in the RMIT Research Repository at:

https://researchbank.rmit.edu.au/view/rmit:31445

Version: Accepted Manuscript

Copyright Statement: (c) Intellect Ltd.

Link to Published Version:

http://dx.doi.org/10.1386/cjmc.6.1.41_1

\section{PLEASE DO NOT REMOVE THIS PAGE}


Footloose transients: International students in Australia and their aspirations for transnational mobility after graduation

Catherine Gomes, RMIT University

\begin{abstract}
Work on the sociocultural aspects of international students tends to largely focus on their experiences within the host country. Research points to the desire of these transient migrants to stay in the host nation through permanent residency rather than return immediately to the homeland once they graduate. While studies in Australia on the sociocultural experiences of international students are necessarily localized and accurate in their assessment of the intentional trajectory of these students post-graduation, my study suggests that a new pattern is emerging that shifts beyond home-host nation connections. Although international students desire Australian permanent residence, they do not necessarily want to remain in Australia. Likewise, neither do they seek to immediately return to their home nations. Through interviews with 60 international students in Melbourne, my research reveals that these students hold aspirations for transnational mobility with ambitions to live and work in the big cities of Europe, North America and Asia, and with plans to return to the home nation eventually or possibly in the future. Their aspirational mobility is encouraged by their experiences in Australia in terms of their ability to form friendship networks with fellow international students rather than with locals, and their sense of belonging to the home nation through rapid developments in communication and media technologies.
\end{abstract}




\section{Keywords}

international students

economic lifestyle migrants

Australia

aspirational transnational mobility

social networks

social media 


\section{Introduction}

I have been examining the sociocultural experiences of international students in Australia since 2011. This work is part of an emerging body of research that seeks to move beyond an education paradigm centred on study and well-being experiences (e.g. accommodation) to a more explicit focus on sociological, anthropological and cultural studies frameworks. Unsurprisingly, any research on international students in Australia concentrates exclusively on their experiences as 'transients' in the host nation. This paper reframes the localized experiences of international students to consider how these students' experiences in the host country help to shape their future ambitions in countries outside the host.

International students have had a presence in Australia since the commencement of the Colombo Plan in 1951. During this early period, the soon-to-be decolonized and former colonies in the British Commonwealth sent sponsored students to Australia to be trained in skills that would assist in the economic, infrastructural and social (e.g. medical and dental) development of these nations. By the 1980s, however, Australia became a global player in the export of education, particularly in the region, by offering courses and qualifications that attracted students from South East Asia and increasingly from north-east and South Asia. In 2010-2011, education services alone brought in AUD\$16.3 billion through full-fee paying international students. This figure does not include the secondary and related industries international students contribute to and support, such as building, hospitality and tourism. Moreover, international students are part of the workforce in Australia as many are part-time workers in various service industries such as hospitality, cleaning and retail. ${ }^{1}$ Since international students are heavily invested in Australia in terms of their time and contribution to the economy as consumers and service providers, this article asks: what are their aspirations for the future and are these aspirations connected to Australia or elsewhere? 
There has been an increasing trend for international students wanting to stay in Australia as skilled migrants. This trend exists even with the much publicized government crackdown on fly-by-night institutions that preyed upon current and future international students with the promise of permanent residency after graduation in the mid- to late 2000s (Lane 2014), and the ensuing tightening of migration laws concerning international student permanent migration and restrictions on international student visa applications (Trounson 2010). In 2010, for instance, a JWT Education survey of 1600 international students revealed that a fifth of them (22 per cent) intended to apply for permanent residency (Harrison 2010). More recently, Robertson (2013) argues that international students are not merely in Australia to study, but rather to invest their time and energy in securing permanent residence. This article presents a different picture of the intended future of international students in Australia. Through in-depth interviews with 60 international students in Melbourne, I put forward the idea that there is a new trend emerging among international students that places transnational mobility at the heart of these transient migrants' experiences while still connecting them to the home nation (country of birth and/or citizenship). Aspirations for transnational mobility, moreover, take precedence over familial and cultural connections to the home nation. I suggest that these aspirations for transnational mobility are encouraged by two factors. First, the friendship networks respondents make with fellow international students rather than with locals. Second, their mobility is also based on their cultural, ethnic and national identities, which in turn are anchored to rapid developments in communication technologies and a student's sense of belonging to the home nation through a variety of means, such as the consumption of media products. This research thus aids in our sociocultural understandings of international students in Australia in ways that move past an analysis of their experiences as international students inside the host to examine their future aspirations beyond their studies and host nation boundaries. 


\section{Methodology}

A total of 60 international students studying at Melbourne higher education institutions were interviewed from March to May 2013, as part of a larger qualitative study involving the identities of transient migrants in Australia. Participants included international students, exchange students, working holiday visa holders, 437 visa holders and bridging visa holders. Table 1 provides demographic details of the participants reported in this article. Participants were recruited through advertisements in the Australian online classified website Gumtree, through colleagues from various Victorian universities (e.g. RMIT University, LaTrobe University and Melbourne University), through international student society groups, through the City of Melbourne and through the snowball effect where participants brought along their friends for scheduled interviews with me. Participants recruited had to be above the age of 18 and living in Australia for a minimum of three months. They were each remunerated with a \$30 gift voucher for their time.

The participants were interviewed in focus groups, small groups and as individuals in addition to a short survey to collate their background information such as age, gender, country of birth/citizenship, ethnicity(s), number of years in Australia to date, course of study/work, media use and hobbies. ${ }^{2}$ The data in this article are reflective of the open-ended questions I asked pertaining to participants' social networks, their impressions of Australian society and entertainment media consumption. While participants addressed all questions, a few international students found certain questions difficult to answer primarily because of their English language skills, even though participants were informed that all interviews were to be conducted in English. The duration of the interviews ranged from 30 to 60 minutes, depending on the willingness of the respondents to go into more depth. 
As indicated in Table 1, the sample included students from a range of countries and across different educational levels (from vocational education and training [VET] and English Language Intensive Courses for Overseas Students [ELICOS] to postgraduate studies [coursework and research higher degree]). Notably there were more men who responded to the project than women and more students from Asia than elsewhere. It is difficult to ascertain why more men than women responded to the survey in terms of gender ratio since gender does not seem to be captured by Australian Education International - the government body dedicated to international education in Australia. There were more Asian international students who participated in this study primarily because Australia attracts high numbers of students from the region. In 2013, China, India, The Republic of Korea, Vietnam and Thailand were the top five nations of origin for international students. International students from these countries contributed 52.1 per cent of the market share in Australia (Australian Education International 2013).

\begin{tabular}{|l|l|}
\hline Gender & Male (33) \\
& Female (27) \\
\hline Age range & 19 to 24 year olds (32) \\
& 25 to 29 year olds (24) \\
& 30 year olds and above (4) \\
\hline Education pursuit & Diploma and Advanced Diploma (9) \\
& Bachelor degree (28) \\
& Masters degree and higher (23) \\
\hline Home country & Bangladesh (2) \\
& Brazil (1) \\
\hline
\end{tabular}




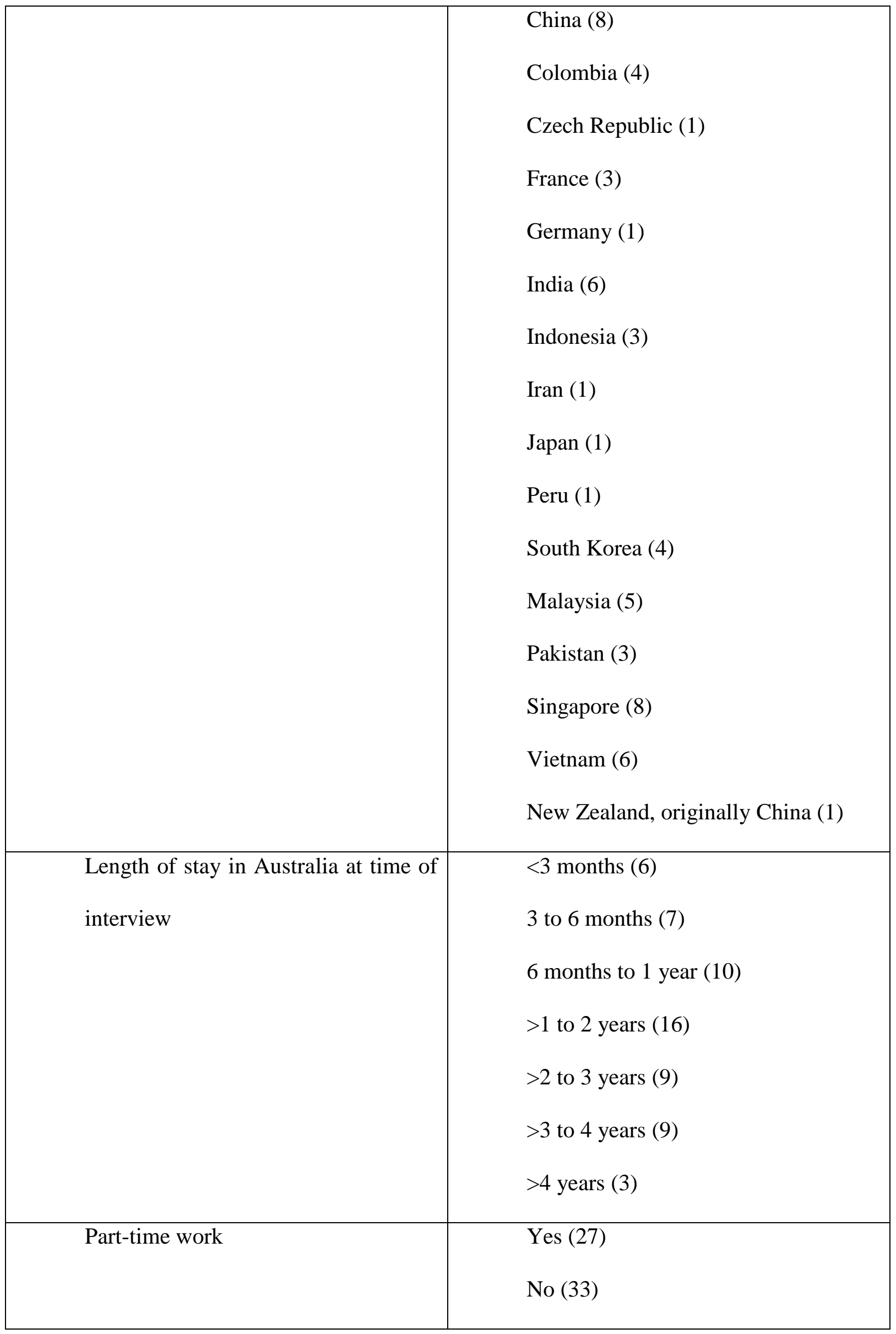


Table 1: Demographic details of participants.

In this research, international students in Australia were asked what their aspirations for the future were. This question was posed specifically in terms of where participants saw themselves after their studies. Asking students where they envisaged themselves allowed me to gain an understanding of their expectations and future orientations in terms of their plans to work, live or enrol in further studies, since government departments such as the Australian Education International do not capture such data. ${ }^{3}$

\section{Aspiring for transnational mobility}

Traditional understandings of migration often view this phenomenon as a permanent one-way journey between home country and adopted nation. Early work by historians such as Oscar Handling's narration of the challenges faced by the American migrant in the 1800s and 1900s in The Uprooted provided us, on the one hand, with an image of migrants as pioneering individuals who left their ancestral homes to create new and better lives for themselves and their families. Yet, on the other hand, this work also provides an honest picture of people who felt culturally and socially isolated as they navigated through unfamiliar physical environments (e.g. from the village to the city). Since Handling's tome was written, government, public, and media actions and interpretations of migration have been brushed with political, humanitarian, racial, economic and nationalist hues as migrants become diverse actors in the global circulation of people. Academia, in the meantime, has responded to the growing need to document and theorize the migrant experience. Such work is not only digested by the scholarly community but also serves to arguably affect governance and public opinion, such as in the cases of border control and multiculturalism. 
Current theoretical understandings of migration, for instance, use a transnational framework where migrants are interpreted as having multiple connections associated with the host and home countries. Research in this area has been inextricably and unsurprisingly linked with Migration and Diaspora Studies (e.g. Fox 2005; Ong and Nonini 1997; Ong 1999, 2006) and increasingly with Cultural and Communication Studies (e.g. Appadurai 1996; Sassen 2001, 2007; Hall 1992). Moreover, researchers have acknowledged that migrants both permanent and temporary - while embedded in their adopted or host country, also have strong connections with the home nation. These connections are aided by communication technology (e.g. Hjorth and Arnold 2012) and media consumption (e.g. Gomes and Alzougool 2013; Abbas 1997: 16-62; Bordwell 2000: 1-17). Of late, a number of pioneering studies on the sociocultural experiences of international students have also emerged (e.g. Martin and Rizvi 2014; Gomes et al. 2014; Fong 2011; Kim 2011). These studies document the ways in which international students create a sense of place while in transience and the difficulties they experience due to cultural differences between themselves and locals in the host nation.

This host-home nexus, however, is becoming increasingly challenged by others who work in the areas of Tourism Studies, Cultural Geography and Mobilities Studies. Here Mobilities Studies pioneers such as John Urry and Mimi Sheller, the founders of a Taylor and Francis journal called Mobilities, have observed that flows in human movements are not static but always constant and vibrant as they involve multiple journeys for economic (work) and lifestyle (family and leisure) reasons. Most importantly, migration within this context is not between home and adopted country nor is it permanent. This article aligns with the twin notions that migration is dynamic and that migrants circulate. Doing so, this study points out that international students are more transnational than thought of before since they aspire to go beyond the home-host nexus. Furthermore the findings of this study point to international 
students as having aspirations for transnational mobility, which are encouraged by their experiences as transients in Australia.

Unlimited transnational mobility - 'Opportunity is the golden word that comes with wanting to get citizenship or a place'

While the majority of respondents (43) stated that they identified with their country of origin or citizenship, only four students claimed they would like to go back to their home country after their studies. The remaining 56 international students interviewed provided a series of responses that revealed their sense of unlimited global mobility. They expressed their desire to go to any part of the world and in any series of combinations: for example, stay in Australia for a period of time before going overseas or back to the home country.

Respondents' answers thus were not specific or patterned (e.g. 'I will return to my home country' or 'I want to stay in Australia'), but instead open and full of unending opportunity for transnational mobility and transient economic migration. An example of this can be seen in the following response from a female undergraduate from Singapore:

I want to go back to Singapore and work, but it's mostly just experience, because I want to do my MBA in UK.... And then maybe, I had big notions of working in Germany or Korea...I think in the end [I want to settle], the long run at Singapore. Because I want my kids to experience the Singapore education. But like, before that before I have kids and stuff, I think I want to live, in either Germany or Korea....If I did get permanent residence [in these countries], it will just be because, it will make the paperwork and stuff easier. It wouldn't be because of any long-term plans and stuff. 
While migration is ‘a young person’s game’ (Wilkerson 2014) with international students in Australia often wanting to gain permanent residence as the desired and purposeful effect of their study (Robertson 2013), from the above response, we can read the participant's interpretation of migrant mobility as something quite different. Even though she would like permanent residence somewhere, she interprets migrant mobility as temporary or transient. Moreover, she feels that migrant mobility is relatively easy to achieve while at the same time expressing a strong desire to eventually return home. A few other respondents (thirteen), for instance, expressed their wish to work overseas before returning to their homeland, while others (nine) highlighted a preference to work in Australia before returning home. 'Home' was understood in this context as their place of birth and/or citizenship and became the default place of eventual residence for many of the international students surveyed in this project.

Regardless of the length of stay in Australia, all participants explained that their host country was not really home to them for a variety of reasons, which included being in an unfamiliar country without their family and friends, having no permanent work and no permanent residence. Such reasons uphold recent work on the challenges international students faced in their everyday host country experience that go beyond their study capabilities (e.g. Kashima and Loh 2006; Sawir et al. 2008; Gomes et al. 2014). ${ }^{4}$

The international students interviewed for this study admitted that when they thought of home, their minds were on their family who they were in regular communication with through phone, Skype, e-mail and increasingly social media. To most of the respondents, family, more so than friends, was a signifier of what they considered to be 'home'. While most international students interviewed in this study were from Asia, they say they did not feel confined by the cultural constraints of practising filial duties in their home countries (e.g. 
looking after parents or getting involved in the family business), even though this prospect was ever present in their minds.

Despite their strong feelings about home (and the host) nations, respondents, for the most part, preferred one of three options: staying in Australia, going elsewhere or a combination of both. They conceded that what determined their decision of place included: finding paid work, doing further study, romantic relationships, travel or combinations thereof. Of the participants, eighteen indicated they wanted to gain permanent residence. However, of this group, four revealed that the basis of their intentions to gain permanent residence or citizenship in Australia was in order to travel and work overseas. In other words, they wanted to use Australia as a springboard for going elsewhere. Meanwhile, seventeen women pointed out how flexible their options were and that going home directly after their studies was not a preference for them. The following extract between a female postgraduate from China (A), a female postgraduate from China (B), a male postgraduate from China (C), a female postgraduate from India (D) and a male diploma student from Indonesia (E) expresses these aspirations for transnational mobility.

Q: what would you like to do after you finish your studies, where would you like to go and would you want to take up permanent residence in Australia after your studies? A: Well for me if I can get the chance, I will try it first. .... [F]or me, I love travelling with like my journey’s passport is very limited.

B: Yeah that is one reason and the other reason for me is I already been in Melbourne almost 4 years It's really long time and China change really fast. If I go back to China I need to start from literal, do everything from there. It's better to try to stay here. 
Q: So for the 3 of you it's sort of like you prefer PR to stay here after you finish your studies, but you prefer travelling actually?

A: Yeah more freedom so that I can go to Europe or USA or UK, wherever I want to go easier, that's the only ...

C: I want to find a job in Australia and see if I can stay to be a resident, but maybe after years. I don’t know how many years, I will still go back to China because my parents live there.... maybe after I get an identity Australian identity [passport].

Q: Would you go back to China for a very long period of time or just [visit]?

D: I think we all think the same now. I think it's the salary that matters. It's the fact that you can earn and the education you have received. You can apply it, and you like the job that you do I think that's what takes something. But it's endless and in my case as well I would say that once I finish I would prefer to get a job in the place where I studied; but if I don't get it that's not the end of the world and apply somewhere else. And you try for it. But I would really like to say that it gives you a bit of a freedom when you get Australian citizenship, or you may not. It could even be European or it could be American, but it's just that it allows you more access to the world and that's something which I think most of us would love to have...... You have access to opportunities not just travelling, but access to opportunities to work and opportunities to be in a place, live in a place without being questioned, or without feeling that you shouldn't be there or you shouldn't be here .... I think opportunity is the golden word that comes with wanting to get citizenship or a place.

D: I would consider $[\mathrm{PR}] \ldots$... but it depends on a lot of things and the Australian government is changing laws for it ....yeah very fast and I would probably never figure on that list, I still would never figure on that list so I'm not of a mindset that I 
will definitely get it. It's good if I can, but it's not the end of the world. I'd probably look somewhere else, and if not, just too bad.

Q: Canada is open.

D: That's right. The second place for Indians.... I would certainly go back to India, definitely yeah.

A: I would like to work either in Australia or other countries and then afterwards go back to China.

E: [Y]eah I would consider PR too. It depends if I get a job or not in here; like if I don't get it's not the end of the world so I can still go back to my own country....For me I would try and like a big city like Tokyo or Canada or Europe, somewhere London maybe [sic].

The above exchange presents a picture of international students who see their future outside their home nations. For B, this was because he felt that China had changed too much and he would have to adjust to the Chinese way of doing things if he returned after his fouryear stint in Australia. Meanwhile, for the rest of the students here, employment opportunities influenced their decision for transnational mobility. However, there is the spectre of home in the above conversation where participants had the option of returning if they were unsuccessful in securing permanent residence or employment in Australia or overseas. Home, unsurprisingly, became the default destination where they were unable to achieve a sustainable transnational transience. The above dialogue also revealed that participants were open to extending their transience in Australia by successfully getting permanent residence or citizenship, yet not confined by place because of visa status. C, for instance, explained later in the interview that she would like to get Australian citizenship because the Australian 
passport allowed her access to more countries than a Chinese passport. She too pointed out that, eventually, she would return to China since her parents were still there.

While they had strong connections to their homeland, the international students in this study saw their future in transnational mobility and having the freedom and opportunity to travel and work wherever they chose. The destinations they aspired to going were the financial hubs of Europe, North America and Asia. They wanted to be transient rather than be rooted, for as long as they were able to do so. This longing for lengthening their transience through aspirational transnational mobility was perhaps an indicator that respondents in this study saw themselves as future economic lifestyle migrants who want to work and travel in countries other than their own and for many of them, this included Australia. Interestingly, these international students did not mention political, ethnic, racial, religious, cultural, class or gender issues as determining their aspirations for transnational mobility.

\section{Future economic lifestyle migrants}

I am cautious not to label the respondents in my study as either economic migrants or lifestyle migrants but rather as a combination of both these groups. This is because the international students I spoke to are not strictly defined by either category. While the international students who expressed a desire for transnational mobility were looking for jobs outside their countries of birth or citizenship, they did not fall comfortably into the economic migrant category. Economic migrants are people who move across borders in search of (better) job opportunities and to improve their financial situations. The international students I interviewed largely originated from Asia, and admitted that job opportunities were better for them in their home countries than they were in Australia and Euro-America. Asian economic tigers such as Singapore, Korea and Hong Kong, together with the economic dragon China, for instance, enjoyed job creation more so than Australia, Europe and North America due to 
their modernity projects, unbridled industrialization and cheaper wages, which have led to multinational companies setting up shop in these countries and using their labour. Moreover, none of the participants in this project expressed financial hardship as a push factor to seeking employment opportunities in Australia or elsewhere.

Likewise, the international students in this study who expressed their desire to attain permanent residence in Australia for lifestyle reasons (i.e. better work-life balance in Australia as compared to their home nations) cannot strictly be labelled as future lifestyle migrants. Describing lifestyle migration, O’Reilly and Benson (2009: 2) explain that it is 'the spatial mobility of relatively affluent individuals of all ages, moving either part-time or fulltime to places that are meaningful because, for various reasons, they offer the potential of a better quality of life'. They also argue that lifestyle after migration is an ongoing process that involves 'the (re)negotiation of the work-life balance, the pursuit of a good quality of life and freedom from prior constraints....[and].... it is through these strategies of reorientation that the migrants seek the greater good in life' (O’Reilly and Benson 2009: 2). While O’Reilly and Benson (2009: 9) suggest that lifestyle migrants also want to leave their old lives behind, I found that the students in this project expressed a desire to return to their homeland in the future to live permanently. Moreover, lifestyle migrants relocate to idyllic locations, but the international students here wanted to enter and work in the financial hubs of Europe, America and Asia.

While it is clear that the international students in this study see their future as involving a transient existence of global travel and work, how do they stay connected to their countries of birth and/or citizenship since all of them state that they consider these countries their home? 


\section{The anchors in transience}

Work in the area of migration in Australia often points to new permanent migrants and citizens creating or being part of existing links to their home countries and cultures in various and increasingly combined ways. These include taking advantage of new advances in communication technology such as social media, Skype and telephony that allows them to keep in touch with family and friends in the home nation (Hjorth 2011), joining national/cultural community groups in the adopted nation, and actively practising national, ethnic and religious observances in the home or with members of the home nation/culture, ethnic and/or religious community(s). Moreover, community print material such as newspapers (e.g. Melbourne's The Epoch Times in Mandarin and also available online in English) and virtual sites (e.g. the Chinese Net a Mandarin website for Chinese in Australia available at http://www.chinese.net.au/) provide support for migrants in Australia to feel both connected to their home nations as well as to their host nation Australia. However, work in this area also points to an exclusive relationship between home and host nations. For international students, their situation differs somewhat primarily because they are on temporary visas. Therefore, while at various levels they make use of the existing structures of communal integration and assimilation set up for permanent migrants and new citizens, there are other ways in which international students anchor themselves to the home nation while in transience in Australia. Their experiences doing so may well arm them with both the confidence and the tools required to continue their time in transience in Australia and elsewhere.

Being transients, international students have learnt through their experience in Australia how to connect to their home countries while still feeling a sense of belonging in Australia. Besides using communication technology (social media, Skype, e-mail and telephony) to connect with their home nations, respondents proactively relied on a mixture of 
methods in their everyday life that allowed them to maintain links to the home nation while at the same time exploring new cultures and people. These included joining national student groups (five) such as the Singapore Students Society, cooking food from their homeland (24), eating at national restaurants such as the Malaysian chain Papa Riche (eight), talking to people about their homeland (four), communicating with people in Australia in their homeland language (twelve), reading/watching/listening to news from their homeland (24), watching films and television shows from their homeland (five), living with people from their homeland (seven), searching online for information on their home country and visiting home nation websites (seven), shopping online and visiting places in Melbourne that remind them of home (four). Meanwhile, seven participants (from Asia and South America) said that Australia reminded them of their home nation. On the surface, the responses also seemed to point to international students maintaining a somewhat exclusive relationship between home and host nation. However, on closer inspection, two themes ran through respondents' answers: social networks (friendship groups) and social media engagement.

\section{Social networks}

This study found that international students in Australia relied on their social networks by allowing them to feel a sense of community in transience while being linked to the home country. Moreover, they lived in a parallel society almost exclusively made up of fellow international students who primarily originated from the home nation and the region. For instance, Asian international students made friends with fellow international students from the Asian region because they felt a sense of cultural and societal familiarity and similarity. This parallel society allowed international students to create both a sense of belonging in Australia yet not to Australia due to disengagement from local society and culture. This was because their status as international students provided them with a community they could 
identify with and feel a sense of belonging to, particularly through the use of their native language and similar experiences. Furthermore, as international students, they depended on each other for support. However, international students also expressed a lack of local friends for the very reasons that bound them together as a community. Connecting with fellow transients rather than locals allowed for a meaningful existence in transience while preventing a sense of belonging or connectivity to Australia.

While literature on permanent migrants and new citizens in Australia (e.g. Hopkins 2011; Evers and Goggin 2012; Harris 2013) and international students elsewhere (e.g. Cemalcilar et al. 2005) often point to the role communication technology plays in connecting the diaspora to the country of birth, this article reveals that more than half (32) of the international students interviewed do not maintain regular contact with friends in their homeland. The justification provided for this was that they wanted to immerse themselves in Australia (e.g. 'Because if I am here I have to think I'm here in Australia - my mind is in Australia’ [Male/ English Language Intensive Courses for Overseas Students/Colombia]) or are too busy (e.g. 'Because my friend is quite busy just studying and me to so I'm not usually like talking or Skyping with my friend' [Male/Undergraduate/Vietnam]). Meanwhile those who actively keep in contact with friends from their homeland do so as a way of connecting to their homeland, even though some of their friends are themselves studying overseas.

All respondents claimed they had friends in Australia, many, if not all of whom were themselves international students from the home country (34), region (36), Australia (26) and elsewhere (27), or a combination thereof. They mostly made friends with people from their courses/English courses (50), previously from bridging courses or from high school (eight), neighbourhood and accommodation (sixteen), workplace (eighteen), hobbies/interests/sports (22), friends of friends (eighteen), online such as CouchSurfing (seven), volunteer groups (21), venues of religious worship such as churches and mosques (thirteen), or randomly on 
the street or at pubs (four). Generally, the international students tended to mix with other international students not only because of ease but also because of similar circumstance.

International students said their friends were largely fellow international students because these were the people whom they met on a regular basis such as in their courses, shared commonality with in terms of similar culture and generally identified with each other as fellow international students with identical issues. More than a third of the respondents (24), for instance, revealed that they made friends with people who were of the same culture as them or spoke similar languages, while sixteen admitted that their friends came from country-based student societies they join, such as the Malaysian Students Society. ${ }^{5}$ The country-based student societies are common clubs found in almost all higher education institutions, particularly universities in Australia. In their own voices, the students explained:

Basically I met most of them through my studies, so the first reason why I spoke to them in the first place was because of the ... I was doing. And then from there you try and find common grounds like yeah, I'm from Singapore, so we find common ground from there, the friendship progressed. And as for those from China and Hong Kong, I basically wanted to widen my social circle, because in Singapore, I only have Singaporean friends, so I like to mix, like international friends, it would be good for my future [Female/Undergraduate/Singapore].

For me, it's like, you make friends that are similar to your language or the way you speak, because then you feel more at home... [Male/Undergraduate/Singapore].

I think actually language is not a barrier, because for example yesterday, I just met three girls from China, another two from Australia and we formed our group, I am the 
mentor and they are the mentees. So when I communicate with them, I find that maybe just the thinking pattern or some cultural things ... barrier in the communication. Because when I first saw that Chinese girl, I just feel we can talk everything. So the other two Australian girls, I just feel that maybe I need to think what I'm talking about, what's valuable to them and whether they will pay attention to what I care about. So when I talk with them, I ask them, what do they care about. So I think maybe the cultural barrier the most important one, rather than language barrier [Female/Undergraduate/China].

From the above examples, it was evident that international students identified and bonded together as a community precisely because of their status as foreigners living and studying in Australia, at least for the duration of their course of study. Most often, they made friends with other international students they met in obvious places such as their courses. The participants felt that only other international students were able to understand the issues they experienced while living overseas, such as the emotional factors of being away from home (e.g. homesickness) and the practical issues connected with living in Australia (e.g. finding suitable accommodation). Having other international students as friends allowed participants to fill the huge gap that has been left because of their separation from not only their homeland but more significantly from family and friends. These findings substantiate existing research on the importance of friendship for overseas students (e.g. Kudo and Simkin 2003; Ying 2002; Kashima and Loh 2006; Kashima and Pillai 2011; Gomes and Alzougool 2013; Gomes et al. 2014).

Participants expressed their views about identifying according to their regional identity (e.g. as Asian) and being friends with others from their region. They suggested that this process of identification provided them with a sense of belonging since they were able to 
understand each other in terms of some similarities in culture (e.g. Singaporeans and Malaysians were familiar with each other's cultures due to their geographical and cultural proximity and shared history as former British colonies). However, participants noted that it was their international student friends from their homeland who provided them with the most comfort and support not only because of their shared culture but also because of a shared language (and accent). For instance, participants who came from non-English-speaking backgrounds revealed how they found great comfort talking with others who spoke the same language and in the same accent as their own. Meanwhile others who spoke English in their homeland enjoyed communicating in their home nation's version of English. Examples here included Singaporeans speaking Singapore English (Singlish) and Malaysians speaking Malaysian English (Manglish).

The international students I spoke to thus rationalized that they were able to connect and identify more with non-locals because of similar and shared experiences with being foreigners and international students. This correlates with Pedro and DeWind's (2004) study of international students in the United States who felt that Americans did not understand their experiences as foreigners while they could not relate to American culture such as interests in sports. International students, as Hendrickson et al. (2011) have noted, were not only comfortable with fellow international students from their home but also with international students from their region and elsewhere. A reason for this, which the participants articulated, was to get to know cultures and people other than their own. In my research, I found that international students created a parallel existence for themselves during their stay in Australia. This also correlates with previous studies on the importance, prominence and necessity of social networks for international students (e.g. Chang et al. 2012; Hendrickson et al. 2011). 


\section{Social media}

Without a doubt, the increasing use and connectivity provided by improvements in communication media and digital technologies, in particular social media, have enabled both permanent and transient migrants to remain connected, more so than ever before, to their national homelands (Hjorth 2011; Hjorth and Arnold 2012). While more than half of the respondents I spoke to said that they stayed in touch with their friends back home through regular two-way communication (e.g. online chatting, telephony and texting), most often the international students kept track of people from the home country through social media. In doing so, the respondents were always up-to-date with the events and conditions of their home country, albeit passively. While respondents were generally diversified in their social media use, almost all respondents (54) had Facebook accounts, which they actively used. ${ }^{6}$ Facebook, in other words, was the social media platform of choice among respondents.

Some of the students I spoke to said that they created Facebook accounts in order to keep in touch with friends back home. Meanwhile others, particularly those from China, created Facebook accounts out of necessity because they discovered that this was a regular communication feature in Australia. This meant they often held two social media accounts, one in English and the other in Chinese (e.g. Weibo the Chinese version of Twitter). While Australian higher education institutions are increasingly using Facebook as a platform to communicate with students, some university courses (particular in media and communication) also require students to study the content of various social networking sites as part of their assessment. Facebook account holders are generally involved in various activities that allow them to maintain connections to the home nation by liking posts, links and photos (including Instagram) (22), reading posts and looking at photos (fifteen), commenting on posts or posting on friends' walls (nineteen), reading links or watching videos (six), posting status updates (21), posting photos (four) and links (two), having 
conversations via the 'chat' function (nineteen), and contributing to group pages (four) and liking their pages (two). Meanwhile nineteen respondents admitted that they visited their Facebook friends’ pages and read the updates in the RSS feeds surreptitiously.

What we can read from the Facebook activities of the respondents is that this platform allowed them to keep wholeheartedly engaged with the activities of their friends from home while not constantly engaged with them through traditional two-way verbal and written conversations. In a recent study I conducted with colleagues on the significance of social media as a form of connectedness between international students and the home nation, we concluded that:

The use of social media to stay in contact with friends and family from the home nation may assist students with forming imaginary bonds with their homelands. Doing so provides international students with virtual home-based support networks, which then allow them the opportunity to pursue and form local social networks with students other than those who come from their countries of birth. (Gomes et al. 2014: 13)

Social media, in other words, allows international students to actively engage with the homeland while overseas.

\section{Conclusion}

Where to next after graduation is always a perplexing question for any student in the midst of formal study. For many students, the end of a diploma, undergraduate or postgraduate course means a new and challenging chapter in their lives as they search for employment and settle 
into working life. Perhaps for some, international relocation in search of work or for work is an essential part of the post-graduation experience, and this can be motivated out of necessity or borne of a will to chase other opportunities in locations further afield to both home and existing host. For international students who are themselves already well-heeled veterans of an overseas lifestyle, the continuation of the international experience after graduation, as this study has shown, is very much a given.

This article highlights how international students in Australia have aspirations for transnational mobility where they see themselves as living, working and/or studying further in countries other than their home nation. While they express devotion to their families in their home nations and are open to living longer in Australia through work and/or permanent residence, they are keen to explore the cities of America, Europe and Asia that are beyond their respective national borders. The students in this study, in other words, see their future outside their homelands. This eagerness for aspirational transnational mobility from international students does not emerge out of nowhere. Instead, it is based on their experiences as international students learning to successfully live in a foreign nation through the social networks they make while in Australia and connecting with the home nation through social media.

\section{Acknowledgements}

This research was supported under Australian Research Council's Discovery Early Career Researcher Award funding scheme (DE130100551) and RMIT University. 


\section{References}

Abbas, A. (1997), Hong Kong: Culture and the Politics of Disappearance, Minneapolis and London: University of Minnesota Press.

Appadurai, A. (1996), Modernity At Large: Cultural Dimensions of Globalization, Minneapolis: University of Minnesota Press.

Australian Education International (2013), End of Year Summary of International Student Enrolment Data - Aust - 2013, Canberra: Australian Government.

Bordwell, D. (2000), Planet Hong Kong: Popular Cinema and the Art of Entertainment, Cambridge, MA and London, UK: Harvard University Press.

Catano, V. M., Wiesner, W. H., Hackett, R. D. and Methot, L. L. (2005), Recruitment and Selection in Canada, Toronto: Nelson Education.

Cemalcilar, Z., Falbo, T. and Stapleton, L. (2005), 'Cyber communication: A new opportunity for international students' adaptation?’, International Journal of Intercultural Relations, 29:1, pp. 91-110.

Chang, S., Alzougool, B., Berry, M., Gomes, C., Smith, S. and Reeders, D. (2012), 'Communicating with international students: How do their social networks impact on where they go to for information?’, in K. Richardson, S. Chang and T. McGrath (eds), 23rd ISANA International Education Conference, 4-7 December, Auckland, New Zealand: ISANA International Education Association, pp. 1-10, http://events.cdesign.com.au/ei/viewpdf.esp?id=314\&file=//srv3/events/eventwin/docs/ pdf/isana2012final00032.pdf. Accessed 3 March 2014.

Evers, C. and Goggin, G. (2012), 'Mobiles, men and migration: Mobile communication and everyday multiculturalism in Australia', in L. Fortunati and J. Vincent (eds), New Media, Migrations and Culture: From Multi- to Interculture, New York and Oxon: Routledge, 78-90. 
Fong, V. L. (2011), Paradise Redefined: Transnational Chinese Students and the Quest for Flexible Citizenship in the Developed World, San Francisco and San Jose: Stanford University Press.

Fox, J. (2005), ‘Unpacking “Transnational Citizenship”’, Annual Review of Political Science, 8, pp. 171-201.

Gaskell, G. (2000), ‘Individual and group interviewing’, in M. W. Bauer and G. Gaskell (eds), Qualitative Researching with Text, Image and Sound, London, California and New Delhi: Sage, pp. 38-56.

Gomes, C. and Alzougool, B. (2013), 'Transnational citizens and identities: International students' self-perceived identities, their social networks and their consumption of entertainment media in Australia', in C. Gomes and S. Chang (eds), 24th ISANA International Education Conference, 3-6 December, Brisbane, Australia: ISANA International Education Association, pp. 1-15, http://proceedings.com.au/isana/docs/2013/Gomes_Catherine.pdf. Accessed 13 March 2014.

Gomes, C., Berry, M., Alzougool, B. and Chang, S. (2014), ‘Home away from home: International students and their identity-based social networks in Australia', Journal of International Students, 4:1, pp. 2-15.

Hall, S. (1992), 'The question of cultural identity’, in S. Hall, D Held and T. McGrew (eds), Modernity and its Futures, Cambridge: Polity Press, pp. 273-326..

Handing, O. (1973), The Uprooted, Boston and Toronto: Little, Brown and Company. Hannam, K., Sheller, M. and Urry, J. (2006-), Mobilities, UK: Taylor and Francis. Harris, A. (2013), Young People and Everyday Multiculturalism, New York and London: Routledge. 
Harrison, D. (2010). 'Residency Lures Foreign Students, in The Age, 15 February,http://www.smh.com.au/national/education/residency-lures-foreignstudents-20100214-nzks.html. Accessed 3 October 2013.

Hendrickson, B., Rosen, D. and Aune, R. K. (2011), ‘An analysis of friendship networks, social connectedness, homesickness, and satisfaction levels of international students', International Journal of Intercultural Relations, 35:3, pp. 281-95.

Hjorth, L. (2011), ‘A case study on mobility, home and being away in Shanghai’, in R. Wilken and G. Goggin (eds), Mobile Technologies and Place, London and New York: Routledge, pp. 140-56.

Hjorth, L. and Arnold, M. (2012), Online@AsiaPacific: Networked Sociality, Creativity and Politics in the Asia-Pacific Region, New York: Routledge.

Hopkins, L. (2011), 'A contested identity: Resisting the category Muslim-Australian’, Immigrants and Minorities, 29:1, pp. 110-31.

Kashima, E. and Loh, E. (2006), 'International students’ acculturation: Effects of international, conational, and local ties and need for closure', International Journal of Intercultural Relations, 30:4, pp. 471-85.

Kashima, E. and Pillai, D. (2011), 'Identity development in cultural transition: The role of need for closure', Journal of Cross-Cultural Psychology, 45:5, pp. 725-39.

Kim, Y. (2011), Transnational Migration, Media and Identity of Asian Women: Diasporic Daughters, New York: Routledge.

Kudo, K., and Simkin, K. A. (2003), 'Intercultural friendship formation: The case of Japanese students at an Australian University’, Journal of Intercultural Studies, 24:2, pp. 91114.

Lane, B. (2014), 'Student Visa “Hangover” under labor worsening’, The Australian, Higher Education Supplement, 19 March, http://www.theaustralian.com.au/higher- 
education/student-visa-hangover-under-labor-worsening/story-e6frgcjx1226858438423\#. Accessed 28 March 2014.

Martin, F. and Rizvi, F. (2014), 'Making Melbourne: Digital connectivity and international students' experience of locality', Media, Culture and Society, 8 August, http://mcs.sagepub.com/content/early/2014/08/07/01634433714541223.abstract?citedby=yes\&legid=spmcs;0163443714541223v1\#cited-by. Accessed 18 August 2014.

Ong, A. (1999), Flexible Citizenship: The Cultural Logics of Transnationality, Durham: Duke University Press. (2006), Neoliberalism as Exception: Mutations in Citizenship and Sovereignty, Durham: Duke University Press.

Ong, A. and Nonini, D. (1997), Ungrounded Empires: The Cultural Politics of Modern Chinese Transnationalism, New York: Routledge.

O’Reilly, K. and Benson, M. (2009), 'Lifestyle migration: Escaping to the good life?’, in M. Benson and K. O’Reilly (eds), Lifestyle Migration. Expectations, Aspirations and Experiences, Farnham: Ashgate.

Pedro, A. and DeWind, J. (2004), 'A cross-atlantic dialogue: The progress of research and theory in the study of international migration', The International Migration Review, 38:3, pp. 828-51.

Rabiee, F. (2004), 'Focus-group interview and data analysis', Proceedings of the Nutrition Society, 63, pp. 655-60.

Robertson, S. (2013), Transnational Student Migrants and the State: The EducationMigration Nexus Transnational Student-Migrants and the State, UK: PalgraveMacmillan.

Sassen, S. (2001), The Global City: New York, London, Tokyo, Princeton and Oxford: Princeton University Press. 
(2007), A Sociology of Globalization, New York and London: W. W. Norton and

Company.

Sawir, E., Marinson, S., Deumert, A., Nyland, C. and Ramia, G. (2008), 'Loneliness and international students: An Australian study', Journal of Studies in International Education, 12:2, pp. 148-80.

Trounson, A. (2010), 'Overseas student numbers plummet', The Australian, Higher Education Supplement, 28 May, http://www.theaustralian.com.au/highereducation/overseas-student-numbers-plummet/story-e6frgcjx-1225872301504. Accessed 28 March 2014.

Wilkerson, I. (2014), 'African american women in U.S. history: Overcoming odds \& proving successful', in Women in Community Conference: The Power of the M.I.N.D., Singapore Management University, Singapore, 28 February-2 March.

Ying, Y. W. (2002), 'Formation of cross-cultural relationships of Taiwanese international students in the United States', Journal of Community Psychology, 30:1, pp. 45-55.

\section{Contributor details}

Catherine Gomes is an Australian Research Council Discovery Early Career Research Fellow based at RMIT University in Melbourne. Her research is a comparative study of transient migrants in Australia and Singapore and their use of media and communication to navigate everyday life.

Contact: 
School of Media and Communication, RMIT University, GPO Box 2476, Melbourne, Victoria 3001, Australia.

E-mail: catherine.gomes@rmit.edu.au

Notes

${ }^{1}$ International students in Australia are permitted to work a maximum of twenty hours per week.

${ }^{2}$ I amended my research strategy from focus groups to individual and small group discussions because I found that both focus group sessions ran between 90 and 150 minutes longer than the expected one hour. Moreover, individual and small group discussions allowed participants to contribute in depth information more freely. Contrary to existing literature (e.g. Gaskell 2000; Rabiee 2004; Catano et al. 2005), I found that individual and small groups allowed participants to contribute in-depth information more freely.

${ }^{3}$ Data on the post-graduation activities of international students in Australia and elsewhere is usually captured by institutional alumni associations. However, this information is random at best since it is dependent on international students actively engaging with the alumni associations of their alma mater.

${ }^{4}$ Work in the area of international students in the globally popular destinations of Australia, Canada, the United Kingdom and the United States often emphasizes the areas of teaching and learning, such as language capabilities rather than everyday existence.

${ }^{5}$ They did not need to be from the same country though where a Malaysian Chinese who spoke Mandarin and/or Chinese dialects such as Hokkien and Cantonese may be friends with 
ethnic Chinese from Singapore where Hokkien is spoken widely and Hong Kong where Cantonese is arguably the common vernacular.

${ }^{6}$ Other social media platforms used by respondents were: Instagram (ten), Twitter (twenty), LinkedIn (ten), QQ (three), Weibo (one), WiChat (three), blogs (eleven), YouTube (two), Tumblr (three). Only two international students revealed that they are not social media users. 